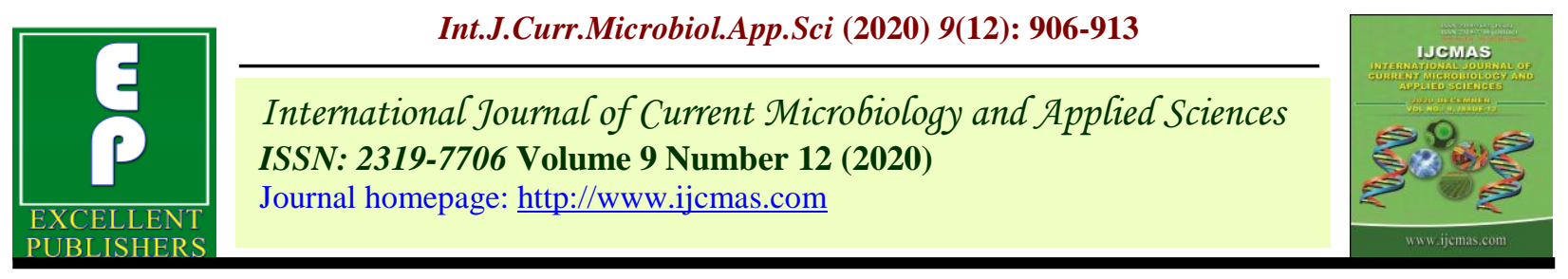

Review Article

https://doi.org/10.20546/ijcmas.2020.912.109

\title{
A Review on Solar and Battery Technology for Sustainable Agricultural Mechanization in India
}

\author{
Arjya Utkalini Sahoo, Gunasagar Sahu, Anup Behera* and Hifjur Raheman \\ Agricultural and Food Engineering Department, IIT Kharagpur, West Bengal, India \\ *Corresponding author
}

\section{A B S T R A C T}

Keywords

Agricultural machinery, Battery technology,

Renewable energy, and Solar energy

Article Info

Accepted:

10 November 2020

Available Online:

10 December 2020

\begin{abstract}
India has abundant solar energy potential, which makes it most suitable renewable energy source for different agricultural applications. Application of solar energy in farm lands for different agricultural operations could reduce the cost of operation without deteriorating the quality of environment. The present review shows that the application of solar photovoltaic system in stationary agricultural operations like irrigation and threshing; and use of battery technology in mobile agricultural machineries like vertical conveyer reaper and mower. Thus, in this paper, a comprehensive review has been made on the application and barriers of solar energy and battery technology in agricultural mechanization.
\end{abstract}

\section{Introduction}

More than $50 \%$ of the total Indian population is directly or indirectly dependent on agriculture. The population of India is 1210 million and the total workforce is 482 million, and about 263 million (55\%) work in agriculture (Mehta et al., 2014). Considering various factors such as past growth rate and changing socio-economic factors, it is estimated that the ratio of agricultural workers to total workers will reduce to $41 \%$ by 2020 (Mehta et al., 2018). Traditional agriculture mainly practices human and animal power sources, which are full of drudgery and timeconsuming process. Thus, for carrying out agricultural operation and timeliness in operation, a step towards mechanization is indispensable. Agricultural mechanization not only reduces the losses but also reduces human drudgery experienced during operation. Thus, for various farm operations, modern mechanical, conventional power sources are used extensively. Due to the adoption of different types of machinery in agricultural activity, power availability has increased from $0.296-2.02 \mathrm{~kW} / \mathrm{ha}$ during the last few decades and food grain production has increased from 0.710- $2.11 \mathrm{t} / \mathrm{ha}$ during 1960-2014 (Singh et al., 2015). Yet, India still needs to increase its food production for the exploding population by increasing power 
availability in agriculture, without decrementing the environment.

Further, the depletion of fossil fuels, an increase in their cost, and environmental pollution due to the burning of fossil fuels has increased the problem of energy deficiency and environmental sustainability (Panwar et al., 2011). Therefore, sustainable development is the need of the hour to meet the increasing energy demand (Naidu, 1996). And a step towards the use of renewable energy sources like solar and battery storage energy in the field of agricultural mechanization is unavoidable. Therefore, more efforts have been made in renewable sources to reduce the consumption of fossil fuels in the agriculture sector and maintain equilibrium between energy input and environmental sustainability. Thus, in this context, a brief review has been presented on the existing literature about the application of solar and battery technology in the field of agriculture for India.

\section{Application of solar energy in agriculture sector in India}

In India, solar energy is available in abundance due to its geographical location nearer to the equator, which has not yet been utilized completely. Solar energy is green energy and almost available everywhere free of cost. Solar energy has been utilized basically in two forms i.e. solar heat energy and solar radiant energy. Solar heat energy has been a promising area of research in the field of drying of crops, water heating, solar cooking, and many heating operations for more than 50 years (Prakash et al., 2014; Kumar et al., 2014; Manju and Sagar, 2017). The solar photovoltaic (SPV) technology has been applied to harness the solar radiant energy on a largescale and it also presents an environmentally favorable alternative to fossil fuel (diesel and electricity) powered conventional water pumps (Kumar et al., 2010 and Mittal et al., 2012). Moreover, the importance of SPV energy to power the water pumps has increased due to the continuous depletion of oil reserves, uneven distribution and ever-increasing cost of electricity, which is a major area of concern for developing countries like India (Abu-Aligah, 2011 and Sontake, 2016). Now, India is destined to harness more power from solar energy by encouraging renewable energy policies and schemes. Hence, this solar photovoltaic technology could be used to exploit solar radiant energy, to run agricultural machinery and increase agricultural productivity without damaging the environment. Various researchers have carried out research works related to the application of SPV on the field of agriculture such as SPV in irrigation systems and different agricultural machinery, which are precisely discussed below:

\section{Application of solar photovoltaic (SPV) technology for Irrigation}

The SPV pumping is an economical and environment friendly technology. India has been using SPV pumps nearly $65 \%$ for irrigation purposes and the remaining 35\% for drinking water purposes (Manju and Sagar, 2017).

Chaurey et al., (1993) installed seven SPV operated pumps on different states of India and studied their field performance and suitability of their applications. The size of the solar array was $1280 \mathrm{~W}$ power and the designed pumping head was $20 \mathrm{~m}$. The performances of all the SPV pumps were found satisfactory. They suggested SPV can replace hand pumps to meet water demand.

Pande et al., (2003) designed and studied the performance of an SPV pump operated drip irrigation system for orchards in the arid region considering various parameters like 
pumps size, water requirements, the diurnal variation in the pressure of the pump due to change in irradiance and pressure compensation in the drippers. The SPV system comprised of a PV pump with $900 \mathrm{~W}$ PV array and $800 \mathrm{~W}$ DC motor pump. The SPV pump with the drip system could cover about 5 ha area of the orchard. Even with the costly SPV and pumps, the benefit-cost ratio for growing pomegranate orchards was evaluated to be above 2 . Therefore the system was considered to be an appropriate technology for horticultural development in the arid region.

Padmavathi et al., (2011) carried out a detailed study on solar water pumps in every household of Bangalore, installed with a solar water pump. They superimposed the solar irradiation data and pumping characteristics of the SPV pump and inferred that PV panels ranging from 60 to $500 \mathrm{~W}$ was suitable for residential buildings of Bangalore city, for filling the overhead tanks.

Mandal and Naskar (2012) studied the relation between the discharge rate of the water pump and solar radiation and the relation between efficiency and the output of the solar photovoltaic water pump. The discharge of the SPV pump increased with radiation and vice versa in the same pattern.

Shinde and Wandre (2015) studied various photovoltaic water pumping systems (PVWPS) and compared them with the diesel water pump. They found that a PVWPS was economical up to $3 \mathrm{~kW}$ power for a village water supply and $1 \mathrm{~kW}$ power for irrigation as compared to a diesel pump in India. The cost of a PVWPS without any subsidy is about $64.2 \%$ of the cost of the diesel pump, over a life cycle of ten years.

Korpale et al., (2016) compared PVWPS with an electrically powered water pump. The
PVWPS consisted of thin-film Cd-Te solar panels, 2HP water pump with MPPT to track the best operating point of PV array. The efficiency of the solar pump was found to increase up to $39 \%$ as compared to the electrically powered system and a maximum flow rate of $69 \mathrm{l} / \mathrm{min}$ and $65 \mathrm{l} / \mathrm{min}$ was obtained with PVWPS and the conventional powered system, respectively.

Chandel et al., (2017) studied a solar water pump in the western Indian Himalayan location. The SPV pump efficiency was improved by incorporating a maximum power point tracking (MPPT) to the PV systems and installing it at an optimum tilt angle for the location under outdoor temperature and irradiance conditions. It was concluded that PVWPS is cost-effective with little maintenance for water pumping requirements.

\section{Application of solar photovoltaic technology for agricultural machinery}

In recent years, SPV technology has been adapted to power agricultural machinery like thresher, grass cutter, paddy harvester.

Amrutesh et al., (2014) studied the performance of a solar grass cutter with linear blades by using a scotch yoke mechanism. The main components of the machine were a $350 \mathrm{~W}$ BLDC motor, 50 Wsolar panel, 12V, 7.2 Ah batteries, and controllers. The performance of the solar grass cutter was not satisfactory as the scotch yoke mechanism didn't give excepted efficiency. The designed SPV system might not be able to provide sufficient power, as the authors mentioned the loading power requirement of about $348 \mathrm{~W}$.

Swetha and Shreeharsha (2015) developed a solar power operated automatic seed sowing machine. The solar sowing machine contained a DC motor, a $10 \mathrm{~W}$ power solar panel, and a $12 \mathrm{~V}$ battery with 4 IR sensors to define the 
territory for movement, digging and sowing. The study claimed that the machine can dig the soil in three rows up to 5 inches by rotating the digging tool. But the applicability of this machine in actual field conditions is uncertain. The capacity of solar panels and batteries might not be sufficient for the machine to run for an hour.

Jadhav et al., (2015) designed and studied the performance of a hand-held solar-powered cutter for paddy crop, which required power of $24 \mathrm{~W}$ with a $12 \mathrm{~V}$ supply. The performance of the SPV paddy cutter was found satisfactory on sunny days, and it could operate for 3 hours continuously in cloudy days by using stored energy in the battery. The time required to fully charge the battery was 4 to 5 hours. However, this type of cutter is not suitable for harvesting cereal crops as they work on the principle of impact cutting. This machine is not ergonomically safer, as a farmer has to work for long hours holding the total weighting of the machine in hand.

Priyanka et al., (2015) fabricated a solarpowered grass cutting machine, which consisted of a solar panel, controllers, a DC motor, blades, rechargeable battery, and cutting blades. The power generated by SPV panels using solar energy was used to operate the grass cutter motor.

Sahu and Raheman (2020) designed and evaluated the performance of an SPV paddy thresher, which consisted of a DC motor, MPPT controller, batteries, controllers, and a DC motor. The performance of the solar energy operated thresher was found satisfactory. The machine could thresh paddy for 7 hours continuously during sunny days and during cloudy, it could thresh paddy for about 2 hours.

Swami et al., (2016) designed a solar PV based power sprayer for agricultural use. The PV sprayer consisted of a $60 \mathrm{~W}$ DC motor, two 100 Wsolarpanels, 12V, 25 Ah batteries with controllers, and spraying nozzles. The solar PV sprayer could spray efficiently even during off-sunshine conditions using battery power. Although, the initial cost of the machine was a little higher compared to conventional sprayer but the running cost was observed to be very less.

Sinha et al., (2018) developed and studied the performance of a solar-powered knapsack sprayer. An anti-clogging filter was installed before the nozzle for trouble-free operation. The solar-powered sprayer had a field capacity of $0.3 \mathrm{ha} / \mathrm{hr}$ with lower physiological energy consumption and discomfort. The system was fully charged by solar energy within two hours of irradiation and was operated continuously for six hours. This ensures quality spray with uniform droplet size in the swath. Similarly, Patil et al., (2014), Yallappa et al., (2016) and Aboegela et al., (2019) also developed solar power operated knapsack sprayer and tested successfully in field.

\section{Barriers in adoption of solar energy}

Efforts are made for better utilization of renewable sources like solar energy but the intermittent and unpredictable characteristic of renewable resources is one of the biggest obstacles to the expansion of renewable energy technology (Deshmukh et al., 2008 and Yoldas et al., 2017). Even though advancement in renewable energy technology has been made but it has not reached the desired point (Kocer et al., 2019). Renewable sources of energy are location specific and useful for the utilization of power at a stationary point. From the literature discussed in previous section, it has been observed that solar energy is location specific and useful for the utilization of power in stationary agricultural machines. The machinery (brush cutter, cereal harvester, sprayer, and seed sowing machine) developed with solar 
photovoltaic technology had uncertain field efficiency. Further, India faces challenges in the adoption of solar energy, which depends on various components such as economic, societal, and institutional factors (Mishra and Behera, 2016).

Therefore, the traditional energy system has evolved and was used in the energy sector. As a result of this evolutionary process, energy storage systems (ESS) have a significant role in it, especially to the problem arising from renewable energy resources. Energy storage technology carries the key to the future development of renewable energy (Divya and Ostergaard, 2009).

\section{Battery technology}

Battery energy storage system (BESS) is the most widely used and popular energy storage technology for power system applications due to its energy density, fast response time, round trip efficiency, cycles, life period, current technological maturity and potential future progress (Divya and Ostergaard, 2009 and Kocer et al., 2019). The batteries are made of stacked cells, where chemical energy is converted to electrical energy and vice versa. The desired battery voltage, as well as current levels, is obtained by electrically connecting the cells in series and parallel. The batteries are rated in terms of their energy and power capacities. Research works have been carried out related to the application of battery technology in agricultural machines, which are precisely reviewed below:

\section{Application of battery technology in the agricultural machinery}

Chieh (2012) developed an electric brush cutter, which consisted of a DC motor to rotate the blades and rechargeable Li-ion battery as the power source. These machines are suitable for cutting grasses and weeds; however, it is not suitable for the cereal crop.
Verma (2016) developed a push-type batterypowered vertical conveyer reaper with $35 \mathrm{~cm}$ cutting width. He used a $12 \mathrm{~V}, 60 \mathrm{Ah}$ rechargeable batteries for operating the header unit of the developed reaper. This battery supplied power to two different DC motors, one motor for cutting unit and another motor for conveying unit. He suggested carrying out harvesting in undulating land for other cereal crops. The developed reaper had a smaller working width and was complex in design. The developed reaper is also unsuitable for the paddy fields, as the paddy field has more undulations.

Kiran et al., (2017) developed a batteryoperated reaper. The reaper consisted of a cutting unit, conveying unit, propelling unit, and power supply unit. An $1100 \mathrm{~W}, 48 \mathrm{~V}$ DC motor was used to operate the reaper. Four 12 $\mathrm{V}$ rechargeable batteries were used to supply power to the motor. But they only operated the machine for $4 \mathrm{~min}$ in a paddy field and evaluated the performance of reaper and reported a field capacity of $0.13 \mathrm{ha} / \mathrm{h}$ with a working width of $60 \mathrm{~cm}$ and forward speed of $2.17 \mathrm{~km} / \mathrm{h}$. However, this reaper requires field testing for a longer duration of time to obtain reliable data.

Sahoo and Raheman (2020) developed a battery-operated walk-behind type electric vertical conveyer reaper. They reported the developed machine harvested paddy with zero carbon emission. The developed machine has less hand vibration and noise as compared to conventional VCR. Thus, the developed electric reaper is an environment-friendly and women-friendly harvesting machine for the small and marginal farmers of India.

Summary and conclusions are as follows:

The solar PV and battery technology have a great future in the field of agriculture in India, only it needs proper awareness about solar 
and battery system and financial encouragement through incentives and subsidy schemes. The important points that are inferred from thestudy are summarized below:

Solar photovoltaic is environment- friendly and economical for stationary agricultural machines like water pumps for irrigation and threshers.

A lot of research work has been conducted on solar operated knapsack sprayer and limited research work is done on solar or electric operated boom sprayers of higher field capacity. Hence, there is a need to develop solar or electric operated boom sprayer.

Battery technology has played a vital role in mechanization of cereal harvesting machinery and grass and shrub cutting machines. Therefore, there is a scope of developing electric agricultural machinery using battery technology.

Efforts need to be made on the hybridization of solar energy, battery technology with the conventional power system for better utilization of renewable resources in farm mechanization.

\section{References}

Aboegela, M. A., Elmeadawy, M., El-Sebaee, I. M., and Al Fakhrany, W. B. (2019). Development A Knapsack Sprayer Powered by Photovoltaic Panel. Journal of Soil Sciences and Agricultural Engineering, 10(12), 907-912.

Abu-Aligah, M. (2011). Design of Photovoltaic Water Pumping System and Compare it with Diesel Powered Pump. Jordan Journal of Mechanical and Industrial Engineering, 5(3).

Amrutesh, P., Sagar, B., and Venu, B. (2014). Solar grass cutter with linear blades by using scotch yoke mechanism. International Journal of Engineering, Research and Applications, 4, 10-21.

Chandel, S. S., Naik, M. N., and Chandel, R. (2017). Review of performance studies of direct coupled photovoltaic water pumping systems and case study. Renewable and Sustainable Energy Reviews, 76, 163-175.

Chaurey, A., Sadaphal, P. M., and Tyaqi, D. (1993). Experiences with SPV water pumping systems for rural applications in India. Renewable energy, 3(8), 961964.

Chieh-Tsung Chi. (2012). A new electric brush cutter. WSEAS Transactions on Systems and Control, 3 (7): 2224-2856.

Deshmukh, M. K., and Deshmukh, S. S. (2008). Modeling of hybrid renewable energy systems. Renewable and sustainable energy reviews, 12(1), 235249.

Divya, K. C., and Østergaard, J. (2009). Battery energy storage technology for power systems-An overview. Electric power systems research, 79(4), 511520.

Jadhav, R. R., Kukadolli, V. D., Mathad, V. G., and Dodamani, S. N. (2015). Design and Performance Analysis of HandHeld Solar Powered Cutter for Paddy. International Journal of Emerging Technology in Computer Science and Electronics (IJETCSE), 14(2), 874-877.

Kiran, I.K.M., Awal, A. M., Ali, R. M. (2017). Development and performance evaluation of a battery operated smallscale reaper. Agricultural Engineering International: CIGR Journal, 19(2): 217-223.

Kocer, M. C., Cengiz, C., Gezer, M., Gunes, D., Cinar, M. A., Alboyaci, B., and Onen, A. (2019). Assessment of battery storage technologies for a Turkish power network. Sustainability, 11(13), 3669. 
Korpale, V. S., Kokate, D. H., and Deshmukh, S. P. (2016). Performance assessment of solar agricultural water pumping system. Energy Procedia, 90, 518-524.

Kumar, A., Kumar, K., Kaushik, N., Sharma, S., and Mishra, S. (2010). Renewable energy in India: current status and future potentials. Renewable and sustainable energy reviews, 14(8), 2434-2442.

Kumar, A., Singh, R., and Prakash, O. (2014). Ashutosh. 2014. Review on Global Solar Drying Status. Agric EngInt: CIGR Journal, 16(4), 161-177.

Mandal, R., and Naskar, R. (2012). A Study of Solar Photovoltaic Application in Irrigation System and Its Performance Analysis in Laboratory Scale. International Journal of Advanced Alternative Energy, Environment and Ecology, 1(1), 1-14.

Manju, S., and Sagar, N. (2017). Progressing towards the development of sustainable energy: A critical review on the current status, applications, developmental barriers and prospects of solar photovoltaic systems in India. Renewable and Sustainable Energy Reviews, 70, 298-313.

Mehta, C. R., Chandel, N. S. and Senthilkumar, T. (2014). Status, challenges and strategies for farm mechanization in India. Agricultural Mechanisation in Asia, Africa and Latin America (AMA), 45(4), 43-50.

Mehta, C. R., Gite, L.P., Khadatkar, A. (2018). Women empowerment through agricultural mechanization in India, Current Science, 114 (9):1934-1940.

Mishra, P., and B. Behera. (2016) "Socioeconomic and environmental implications of solar electrification: Experience of rural Odisha." Renewable and Sustainable Energy Reviews 56: 953-964.
Mittal, M. L., Sharma, C., and Singh, R. (2012, August). Estimates of emissions from coal fired thermal power plants in India. In 2012 International emission inventory conference (pp.13-16).

Naidu, B. S. K. (1996). Indian scenario of renewable energy for sustainable development. Energy policy, 24(6), 575-581.

Padmavathi, K., and Daniel, S. A. (2011). Studies on installing solar water pumps in domestic urban sector. Sustainable Cities and Society, 1(3), 135-141.

Pande, P. C., Singh, A. K., Ansari, S., Vyas, S. K., and Dave, B. K. (2003). Design development and testing of a solar PV pump based drip system for orchards. Renewable Energy, 28(3), 385-396.

Panwar, N. L., Kaushik, S. C., and Kothari, S. (2011). Role of renewable energy sources in environmental protection: A review. Renewable and sustainable energy reviews, 15(3), 1513-1524.

Patil, A. P., Chavan, S. V., Patil, A. P., and Geete, M. H. (2014). Performance evaluation of solar operated snapsack sprayer. Agricultural Engineering Today, 38(3), 15-19.

Prakash, O., and Kumar, A. (2014). Ancient and Present Trends in Solar Drying Systems. Agricultural Engineering International: CIGR Journal, 16(4), 161177.

Priyanka, L., Nagaraju, J., and Reddy, M. V. K. (2015). Fabrication of Solar Powered Grass Cutting Machine. IJMETMR, July.

Sahoo, A.U., Raheman, H. (2020). Development of an electric reaper: a clean harvesting machine for cereal crops. Clean Technologies and Environmental Policy, Pp. 1-10.

Sahu, G., and Raheman, H. (2020). Development of a Renewable Energy Operated Paddy Thresher. Journal of The Institution of Engineers (India): 
Series A, 101(4), 657-668.

Shinde, V. B., and Wandre, S. S. (2015).

Solar photovoltaic water pumping system for irrigation: a review. African Journal of Agricultural Research, 10(22), 2267-2273.

Singh, R.S., Singh, S., Singh, S.P. (2015).

Farm power and Machinery Availability

on India farms, Agricultural Engineering today, 39(1): 45-56.

Sinha, J. P., Singh, J. K., Kumar, A. D. A. R. S. H., and Agarwal, K. N. (2018). Development of solar powered knapsack sprayer. Indian Journal of Agricultural Sciences, 88(4), 590-595.

Sontake, V. C., and Kalamkar, V. R. (2016). Solar photovoltaic water pumping system-A comprehensive review. Renewable and Sustainable Energy Reviews, 59, 1038-1067.

Swami, V., Chauhan, D. K., Santra, P., and Kothari, K. (2016). Design and Development of Solar PV based Power
Sprayer for Agricultural Use. Annals of Arid Zone, 55(1\&2), 51-57.

Swetha, S., and Shreeharsha, G. H. (2015). Solar operated automatic seed sowing machine. International Journal of Advanced Agricultural Sciences and Technology, 4(1), 67-71.

Verma, N. K. (2016). Development of push type battery powered reaper, A M-Tech Dissertation, CAET, AAU, Godra.

Yallappa, D., Palled, V., and Veerangouda, M. (2016, October). Development and evaluation of solar powered sprayer with multi-purpose applications. In 2016 IEEE Global Humanitarian Technology Conference (GHTC) (pp. 16). IEEE.

Yoldas, Y., Önen, A., Muyeen, S.M., Vasilakos, A.V., Alan, 'I. (2017). Enhancing smart grid with microgrids: Challenges and opportunities. Renewable and Sustainable Energy Reviews. 72, 205-214.

\section{How to cite this article:}

Arjya Utkalini Sahoo, Gunasagar Sahu, Anup Behera and Hifjur Raheman. 2020. A Review on Solar and Battery Technology for Sustainable Agricultural Mechanization in India. Int.J.Curr.Microbiol.App.Sci. 9(12): 906-913. doi: https://doi.org/10.20546/ijcmas.2020.912.109 